\title{
Gastric Outlet Obstruction due to Intramural Duodenal Hematoma after Endoscopic Biopsy: Possible Therapeutic Role of Endoscopic Dilation
}

\author{
Mahmud Samra Tarek Al-Mouradi Charles Berkelhammer \\ Department of Internal Medicine, Advocate Christ Medical Center, Oak Lawn, IL, USA
}

\section{Keywords}

Intramural duodenal hematoma - Endoscopic biopsy · Gastric outlet obstruction · Endoscopic dilation

\begin{abstract}
Intramural duodenal hematoma (IDH) is an extremely rare complication after endoscopic biopsy. It typically presents with symptoms due to duodenal obstruction, which include abdominal pain and bilious vomiting. The hematoma may also expand and cause ampullary compression leading to pancreatitis and cholestasis. Computed tomography scan and abdominal ultrasound are the most common diagnostic modalities. Treatment is usually conservative, with bowel rest, nasogastric suctioning and total parenteral nutrition. Refractory cases have been described, requiring endoscopic therapy or surgical drainage. We describe a 28-year-old healthy male who presented with acute abdominal pain a few hours after a routine esophagogastrodudenoscopy with biopsies was performed. Following an otherwise uneventful endoscopy, he developed a gastric outlet obstruction and pancreatitis secondary to an IDH. The patient was managed conservatively. Resolution of his gastric outlet obstruction occurred immediately after gentle passage of the endoscope through the narrowed duodenal lumen.
\end{abstract}




\section{Case Reports in Gastroenterology}

Case Rep Gastroenterol 2018;12:692-698

DOI: $10.1159 / 000494967$

(C) 2018 The Author(s). Published by S. Karger AG, Basel www.karger.com/crg

Samra et al.: Role of Endoscopic Dilation in Gastric Outlet Obstruction

\section{Introduction}

Intramural duodenal hematoma (IDH) is an uncommon condition, first described in 1838 by McLauchlan [1]. The majority of cases are seen in children secondary to blunt abdominal trauma. It has been also reported in patients with underlying risk factors, such as coagulopathy, platelet dysfunction, anticoagulant therapy and as a rare complication after endoscopic interventions [2-12].

The first IDH following endoscopic biopsy was reported in 1989 by Zinelis [2]. Upper gastrointestinal endoscopy is a relatively safe and well-established diagnostic procedure for the evaluation of a myriad of gastrointestinal complaints. Complications after upper endoscopy are rare. These are most often related to sedation, methemoglobinemia (if topical anesthetics are used), infection, bleeding and perforation. IDH is an exceptionally rare complication following endoscopic biopsy, especially in the absence of risk factors. It is more frequently seen in children secondary to blunt trauma. In adults without risk factors, it has only been reported in several case reports.

\section{Case Report}

A 28-year-old healthy male presented with epigastric pain radiating to his back, nausea, vomiting (nonbloody, nonbilious), and intractable hiccups within a few hours after an upper endoscopy. The endoscopy had been performed for evaluation of reflux, solid food dysphagia, and 9-lb weight loss over 6 months, of a 185-lb initial weight. The endoscopy had revealed reflux esophagitis and was otherwise normal. Duodenal, gastric, and esophageal biopsies were taken using a standard sized biopsy forceps. He denied any recent trauma or alcohol use and had no history of bleeding tendencies or medication use. Physical examination was significant for tachycardia, epigastric fullness, and tenderness. Bowel sounds were present. Stool was negative for occult blood. Laboratory evaluation showed a white blood count of $13,700 / \mathrm{mm}^{3}$, lipase 10,830 IU/L, and bilirubin of $0.9 \mathrm{mg} / \mathrm{dL}$ on admission (peaking at $3.5 \mathrm{mg} / \mathrm{dL}$ on day 5 , with a direct bilirubin of $1.6 \mathrm{mg} / \mathrm{dL}$ ). Other liver biochemistries including AST $19 \mathrm{IU} / \mathrm{L}$, ALT $41 \mathrm{IU} / \mathrm{L}$, alkaline phosphatase $69 \mathrm{IU} / \mathrm{L}$, and albumin $4.5 \mathrm{~g} / \mathrm{dL}$ were normal. Hematological testing revealed INR 1.1, Von Willebrand Factor $84 \mathrm{IU} / \mathrm{dL}$, normal factors VIII, IX, XIII, and platelet function. CT scan of the abdomen with oral contrast was remarkable for thickening of the duodenal wall to $5 \mathrm{~cm}$ with lack of emptying of contrast beyond the pylorus and a "coilspring sign" (Fig. 1). Pathology of the biopsies taken prior to admission showed normal mucosa. Nasogastric suction yielded the immediate return of $1.3 \mathrm{~L}$ of nonbilious, nonbloody fluid. The patient was treated with bowel rest, proton pump inhibitor therapy, and nasogastric tube suction. Total parenteral nutrition was not required. Due to persistent gastric outlet obstruction, endoscopy was performed on day 5 . This showed a gastric outlet obstruction caused by a submucosal duodenal hematoma (Fig. 2). There was compression of the ampulla of Vater (Fig. 3). The endoscope was gently advanced through the narrowed duodenal lumen. This simple passage of the endoscope appeared to open up the duodenal narrowing. Endoscopic balloon dilation was not elected, since the simple passage of the endoscope appeared to open the narrowing sufficiently to relieve the gastric outlet obstruction. Immediately following the 


\section{Case Reports in Gastroenterology}

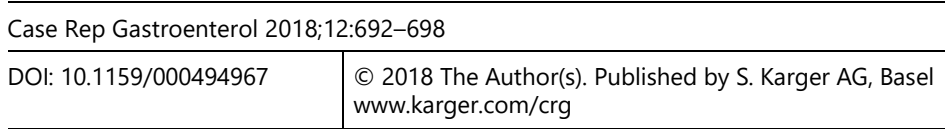
www.karger.com/crg

Samra et al.: Role of Endoscopic Dilation in Gastric Outlet Obstruction

procedure, the patient was able to tolerate oral intake. He was discharged on a general diet on day 7.

\section{Discussion}

Upper endoscopy is commonly performed and carries a low risk of adverse events. Large series report adverse event rates of 1 in 200 to 1 in 10,000 and mortality rates ranging from none to 1 in 2,000 [13]. Some of those recognized adverse events include cardiopulmonary events related to sedation and analgesia, bleeding, and perforation. In recent years, IDH has been recognized as a rare complication after endoscopy. In one study the incidence was estimated to be 1 in 1,250 [3].

The majority of cases have been seen in children following blunt trauma. IDH after endoscopic biopsy usually occurs in patients with predisposing risk factors such as coagulopathy, platelet dysfunction such as von Willebrand's disease, and anticoagulant therapy [2, 3, 5-7]. Other risk factors include graft versus host disease and bone marrow transplant [7]. It has also been described as a rare complication following endoscopic interventions, including injection sclerotherapy and endoscopic retrograde cholangiopancreatography with sphincterotomy. Our goal was to review reported cases of IDH complicating endoscopy in adults. To the best of our knowledge, only several case reports on IDH following endoscopy in adults have been described (Table 1).

Intramural hematomas of the gastrointestinal tract tend to occur mostly in the duodenum. This is mainly due to the fixed retroperitoneal position of the duodenum, its rich submucosal vascular plexus, and the lack of a well-developed serosal layer [12]. Traction on the duodenal mucosa by the endoscopic forceps during a biopsy may strip a substantial area of mucosa away from the immobile wall beneath it, tearing those vessels. It has been suggested that the endoscopic forceps should not be advanced more than $3 \mathrm{~cm}$ beyond the tip of the endoscope to grasp the mucosa [2] to minimize shearing.

The symptoms of IDH are related to duodenal obstruction and can present with abdominal pain and bilious vomiting. It may also compress the ampulla and lead to pancreatitis, as occurred in our case. To prevent pancreatitis, it has been proposed that duodenal mucosa be sampled as far away from the papilla as possible [3].

Based on this review of the literature, the onset of symptoms of IDH can vary from immediately after to up to 4 days post-endoscopy. Variable imaging techniques used to confirm the diagnosis include ultrasound, CT scan, MRI, upper gastrointestinal series, and endoscopy. The barium study may show a "coil spring sign," which has been described as pathognomonic of intramural hematoma [4].

The two established management approaches are conservative or surgical. Conservative management, which includes nasogastric tube suctioning, nothing by mouth, and supportive therapy with intravenous fluids and sometimes intravenous nutrition, is preferred due to favorable outcomes as evidenced in this case series. It is possible that the endoscopy performed in our case assisted in "dilating" the passageway through the duodenum via the endoscope traversing through the lumen and thereby expanding open the duodenal narrowing. This raises the possibility of applying endoscopic balloon dilation as another potential method of alleviating the gastric outlet obstruction. Although it is possible that our patient's gastric 
outlet obstruction resolved simply with the passage of time, it was visually very apparent that the endoscopic passage through the narrowed duodenal lumen led to opening up of the gastric outlet obstruction. Our observation of improvement immediately after simple passage of the endoscope through the narrowed duodenal lumen, and the possibility of applying endoscopic balloon dilation if needed, raises an alternate potential therapy. Optimal timing of such endoscopic intervention remains to be determined. Surgical intervention is not pursued unless there is no improvement with conservative therapy, perforation is suspected, or if the patient is hemodynamically unstable. The period of time before considering surgery is controversial but appears to be between 7 and 14 days [14-16].

In summary, we describe the rare complication of IDH following upper endoscopy with standard duodenal biopsies in an adult without any predisposing factors. The IDH was severe enough to cause a gastric outlet obstruction and acute pancreatitis. The acute pancreatitis was caused by ampullary compression by the IDH. Our patient responded to conservative therapy. We hypothesize that simple endoscopic passage through the duodenal stenotic area may assist in resolution of the gastric outlet obstruction. This raises the potential of endoscopic balloon dilation as a possible treatment, but this remains to be explored. We conclude that IDH should be considered in patients presenting with symptoms of gastric outlet obstruction and/or acute pancreatitis following an upper endoscopy with duodenal biopsies, even in the absence of any coagulopathy or other identifiable risk factors.

\section{Statement of Ethics}

Written informed consent was obtained from the patient for the publication of this case report and accompanying images. A copy of the written consent is available for review by the Editor-in-Chief of this journal.

\section{Disclosure Statement}

The authors declare no financial or competing interests related to the publication of this paper.

\section{References}

1 McLauchlan J. Fatal false aneurysmal tumour occupying nearly the whole of the duodenum. Lancet. 1838 May;2:203-5.

2 Zinelis SA, Hershenson LM, Ennis MF, Boller M, Ismail-Beigi F. Intramural duodenal hematoma following upper gastrointestinal endoscopic biopsy. Dig Dis Sci. 1989 Feb;34(2):289-91.

3 Guzman C, Bousvaros A, Buonomo C, Nurko S. Intraduodenal hematoma complicating intestinal biopsy: case reports and review of the literature. Am J Gastroenterol. 1998 Dec;93(12):2547-50.

4 Felson B, Levin EJ. Intramural hematoma of the duodenum: a diagnostic roentgen sign. Radiology. 1954 Dec;63(6):823-31.

5 Hoenisch K, Prommegger R, Schwaighofer H, Freund M, Schocke M, Vogel W, et al. Intramural duodenal hematoma after upper gastrointestinal endoscopy. Wien Med Wochenschr. 2011 Sep;161(17-18):441-4. 


\section{Case Reports in Gastroenterology} \begin{tabular}{l|l}
\hline Case Rep Gastroenterol 2018;12:692-698 \\
\hline DOI: 10.1159/000494967 & $\begin{array}{l}\text { @ 2018 The Author(s). Published by S. Karger AG, Basel } \\
\text { www.karger.com/crg }\end{array}$
\end{tabular}

Samra et al.: Role of Endoscopic Dilation in Gastric Outlet Obstruction

6 Lipson SA, Perr HA, Koerper MA, Ostroff JW, Snyder JD, Goldstein RB. Intramural duodenal hematoma after endoscopic biopsy in leukemic patients. Gastrointest Endosc. 1996 Nov;44(5):620-3.

7 Worynski A, Zimmerman M, Herrmann RP, Forbes GM. Intramural duodenal haematoma following endoscopic biopsy in a bone marrow transplant patient. Aust N Z J Med. 1998 Dec;28(6):843-4.

8 Sgouros SN, Karamanolis G, Papadopoulou E, Papageorgiou G, Stefanides G, Nastos H, et al. Postbiopsy intramural hematoma of the duodenum in an adult with Noonan's syndrome. J Gastroenterol Hepatol. 2004 Oct;19(10):1217-9.

9 Lloyd GM, Sutton CD, Marshall LJ, Jameson JS. Case of duodenal haematoma treated with ultrasound guided drainage. ANZ J Surg. 2004 Jun;74(6):500-1.

10 Chen YY, Su WW, Soon MS, Yen HH. Gastrointestinal: intramural hematoma of the duodenum. J Gastroenterol Hepatol. 2006 Jun;21(6):1071.

11 Galea LA, Andrejevic P, Vassallo M. A strange case of acute abdomen. South Med J. 2009 Feb;102(2):186-7.

12 Jones WR, Hardin WJ, Davis JT, Hardy JD. Intramural hematoma of the duodenum: a review of the literature and case report. Ann Surg. 1971 Apr;173(4):534-44.

13 Ben-Menachem T, Decker GA, Early DS, Evans J, Fanelli RD, Fisher DA, et al.; ASGE Standards of Practice Committee. Adverse events of upper GI endoscopy. Gastrointest Endosc. 2012 Oct;76(4):707-18.

14 Margolis IB, Carnazzo AJ, Finn MP. Intramural hematoma of the duodenum. Am J Surg. 1976 Dec;132(6):779-83.

15 Takishima T, Hirata M, Kataoka Y, Naito T, Ohwada T, Kakita A. Delayed development of obstructive jaundice and pancreatitis resulting from traumatic intramural hematoma of the duodenum: report of a case requiring deferred laparotomy. J Trauma. 2000 Jul;49(1):160-2

16 Jewett TC Jr, Caldarola V, Karp MP, Allen JE, Cooney DR. Intramural hematoma of the duodenum. Arch Surg. 1988 Jan;123(1):54-8.

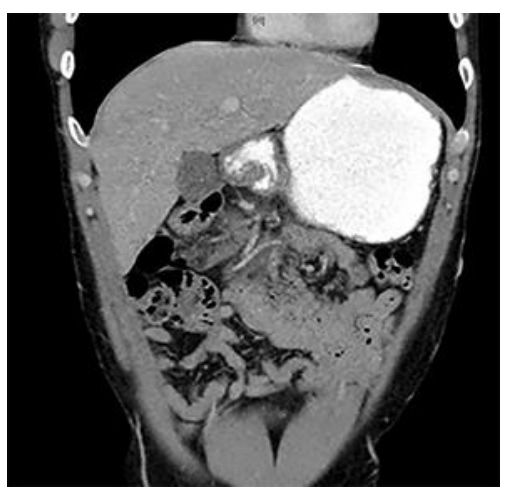

Fig. 1. CT scan: coronal view showing poor emptying of contrast from the stomach and thickened "coilspring" appearance of the duodenal wall. 

www.karger.com/crg

Samra et al.: Role of Endoscopic Dilation in Gastric Outlet Obstruction

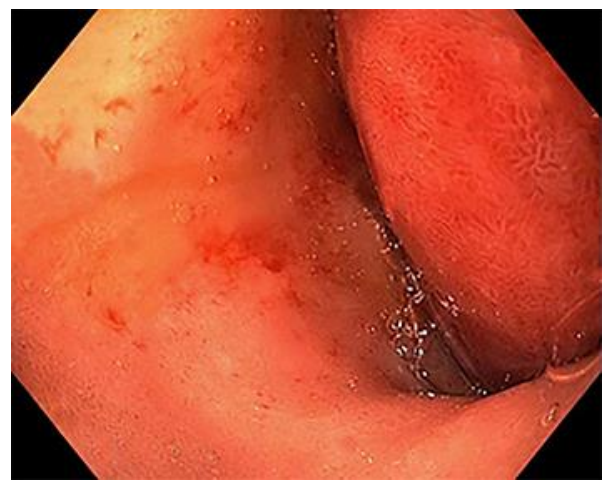

Fig. 2. Endoscopic view of intramural duodenal hematoma.

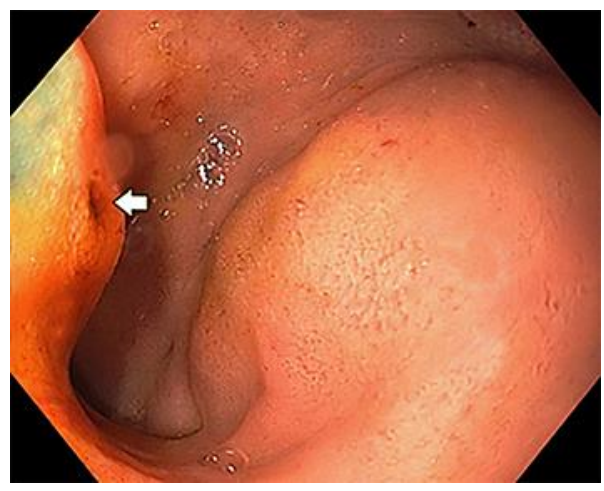

Fig. 3. Ampullary compression (arrow) by duodenal hematoma. 


\section{Case Reports in Gastroenterology}

\begin{tabular}{l|l}
\hline Case Rep Gastroenterol 2018;12:692-698 \\
\hline DOI: 10.1159/000494967 & $\begin{array}{l}\text { ( 2)18 The Author(s). Published by S. Karger AG, Basel } \\
\text { www.karger.com/crg }\end{array}$ \\
\hline
\end{tabular}

Samra et al.: Role of Endoscopic Dilation in Gastric Outlet Obstruction

Table 1. Reported cases of IDH after endoscopic biopsy in adults

\begin{tabular}{|c|c|c|c|c|c|c|c|c|c|c|}
\hline $\begin{array}{l}\text { Case } \\
\text { No. }\end{array}$ & $\begin{array}{l}\text { First } \\
\text { author }\end{array}$ & $\begin{array}{l}\text { Age, } \\
\text { years/ } \\
\text { Sex }\end{array}$ & $\begin{array}{l}\text { Indica- } \\
\text { tion }\end{array}$ & $\begin{array}{l}\text { Plate- } \\
\text { lets, } n\end{array}$ & $\begin{array}{l}\text { Coagu- } \\
\text { lation }\end{array}$ & $\begin{array}{l}\text { Anti- } \\
\text { coagu- } \\
\text { lation }\end{array}$ & Onset & Biopsies & Management & $\begin{array}{l}\text { Additional compli- } \\
\text { cations }\end{array}$ \\
\hline 1 & $\begin{array}{l}\text { Zinelis } \\
{[2]}\end{array}$ & $23 \mathrm{M}$ & $\begin{array}{l}\text { Malab- } \\
\text { sorption }\end{array}$ & 62,000 & $\begin{array}{l}\text { PT/PTT } \\
\text { normal }\end{array}$ & None & 1day & $\begin{array}{l}2 \text { mucosal biopsies with stand- } \\
\text { ard forceps }\end{array}$ & $\begin{array}{l}\text { Conservative; oral intake } \\
\text { after } 17 \text { days }\end{array}$ & $\begin{array}{l}\text { Transfusion re- } \\
\text { quirement }\end{array}$ \\
\hline 2 & $\begin{array}{l}\text { Lipson } \\
\text { [6] }\end{array}$ & $32 \mathrm{~F}$ & GVHD & 50,000 & $\begin{array}{l}\mathrm{PT} / \mathrm{PTT} \\
\text { normal }\end{array}$ & None & $16 \mathrm{~h}$ & $\begin{array}{l}\text { Standard biopsies of duode- } \\
\text { num }\end{array}$ & $\begin{array}{l}\text { Surgical evacuation with } \\
\text { drain placement after } 3 \\
\text { weeks }\end{array}$ & $\begin{array}{l}\text { Pneumonia, intra- } \\
\text { abdomi- } \\
\text { nal hemorrhage, } \\
\text { ARDS; death after } \\
\text { surgery }\end{array}$ \\
\hline 3 & $\begin{array}{l}\text { Lipson } \\
{[6]}\end{array}$ & $36 \mathrm{~F}$ & GVHD & 54,000 & $\begin{array}{l}\mathrm{PT} / \mathrm{PTT} \\
\text { normal }\end{array}$ & None & $6 \mathrm{~h}$ & $\begin{array}{l}\text { Standard duodenal biopsy } \\
\text { showing villous congestion }\end{array}$ & $\begin{array}{l}\text { Conservative; home after } \\
\text { day } 11\end{array}$ & None \\
\hline 4 & $\begin{array}{l}\text { Worinski } \\
{[7]}\end{array}$ & $23 \mathrm{M}$ & GVHD & 46,000 & $\mathrm{n} / \mathrm{a}$ & None & 4 days & $\begin{array}{l}2 \text { duodenal biopsies taken } \\
\text { from } 2 \text { nd and 3rd part of duo- } \\
\text { denum using standard biopsy } \\
\text { forceps, showing moderate } \\
\text { GVHD }\end{array}$ & Conservative & $\begin{array}{l}\text { Encephalopathy, } \\
\text { seizure, death at } \\
\text { day } 13\end{array}$ \\
\hline 5 & $\begin{array}{l}\text { Lloyd } \\
{[9]}\end{array}$ & $18 \mathrm{~F}$ & Diarrhea & Normal & $\begin{array}{l}\mathrm{PT} / \mathrm{PTT} \\
\text { normal }\end{array}$ & None & $\begin{array}{l}\text { Next } \\
\text { day }\end{array}$ & $\begin{array}{l}\text { Standard biopsy forceps bi- } \\
\text { opsy from the duodeno-jejunal } \\
\text { flexure showing normal mu- } \\
\text { cosa }\end{array}$ & $\begin{array}{l}\text { Conservative for } 15 \text { days } \\
\text { then US-guided drainage } \\
\text { of hematoma with drain } \\
\text { placement; home after } \\
25 \text { days }\end{array}$ & None \\
\hline 6 & $\begin{array}{l}\text { Sgouros } \\
{[8]}\end{array}$ & $32 \mathrm{M}$ & Diarrhea & Normal & $\begin{array}{l}\text { PT/PTT } \\
\text { normal }\end{array}$ & None & $6 \mathrm{~h}$ & $\begin{array}{l}\text { Standard forceps; } \\
\text { normal mucosa }\end{array}$ & $\begin{array}{l}\text { Conservatively; oral in- } \\
\text { take at } 3 \text { weeks }\end{array}$ & None \\
\hline 7 & $\begin{array}{l}\text { Chen } \\
{[10]}\end{array}$ & $39 \mathrm{M}$ & $\begin{array}{l}\text { Not } \\
\text { reported }\end{array}$ & $\begin{array}{l}\text { Not re- } \\
\text { ported }\end{array}$ & $\begin{array}{l}\text { Not re- } \\
\text { ported }\end{array}$ & $\begin{array}{l}\text { Not } \\
\text { re- } \\
\text { ported }\end{array}$ & $\begin{array}{l}\text { Not } \\
\text { re- } \\
\text { ported }\end{array}$ & Not reported & $\begin{array}{l}\text { Conservatively; oral in- } \\
\text { take after } 1 \text { week }\end{array}$ & None \\
\hline 8 & $\begin{array}{l}\text { Galea } \\
{[11]}\end{array}$ & $30 \mathrm{M}$ & Diarrhea & Normal & $\begin{array}{l}\text { Not re- } \\
\text { ported }\end{array}$ & None & $\begin{array}{l}\text { A few } \\
\text { hours }\end{array}$ & Not reported & $\begin{array}{l}\text { Surgical; home after } 3 \\
\text { weeks }\end{array}$ & $\begin{array}{l}\text { Large retroperito- } \\
\text { neal hematoma }\end{array}$ \\
\hline 9 & $\begin{array}{l}\text { Hoenisch } \\
{[5]}\end{array}$ & $21 \mathrm{~F}$ & $\begin{array}{l}\text { Dys- } \\
\text { pepsia }\end{array}$ & $\mathrm{n} / \mathrm{a}$ & $\begin{array}{l}\text { PT } \\
\text { normal }\end{array}$ & None & $\begin{array}{l}\text { Imme- } \\
\text { diate }\end{array}$ & $\begin{array}{l}6 \text { routine standard forceps bi- } \\
\text { opsies; normal mucosa }\end{array}$ & $\begin{array}{l}\text { Conservative; oral intake } \\
\text { after } 12 \text { days; home after } \\
19 \text { days }\end{array}$ & None \\
\hline 10 & $\begin{array}{l}\text { Samra } \\
\text { (this } \\
\text { report) }\end{array}$ & $28 \mathrm{M}$ & $\begin{array}{l}\text { Dys- } \\
\text { phagia }\end{array}$ & 244,000 & $\begin{array}{l}\mathrm{PT} / \mathrm{PTT} \\
\text { normal }\end{array}$ & None & $\begin{array}{l}\text { A few } \\
\text { hours }\end{array}$ & $\begin{array}{l}\text { Standard biopsy forceps; nor- } \\
\text { mal duodenum; distal esopha- } \\
\text { gus }\end{array}$ & $\begin{array}{l}\text { Conservative; } \\
\text { oral intake after } 1 \text { week }\end{array}$ & None \\
\hline
\end{tabular}

